\title{
WOMEN, BUREAUCRACY AND DEVELOPMENT IN NIGERIAN: A CONCEPTUAL PERSPECTIVE
}

\author{
https://doi.org/10.47743/jopafl-2021-22-07
}

\author{
Bridget Onajite URHIBO \\ Department of Political Science \\ Faculty of the Social Sciences, Delta State University, \\ Abraka, Nigeria \\ jiteb02@yahoo.com
}

\begin{abstract}
The introduction of diversity management programme in the Nigerian public service would constitute an effort to celebrate diversity by increasing supportive, not just neutral work environment for women but minority ethnic groups in the country. Against this backdrop, this study addresses the concerns of women not hired in senior public management positions. This paper adopted the analytical method and relies on secondary data and utilizes the content analysis for interpretation of data collected. This paper argues that in offering women the opportunity to access economic resources as well as to disentangle their identities from those of their families, diversity management programs will provide the space for women in Nigeria to clearly define their role as equal partners in the sustainable development process of the nation. The paper therefore concludes that the success of the government will increase if it is determined by its managers' ability to naturally tap the full potentials of a diverse workforce that comprise of men, women and young adults.
\end{abstract}

Keywords: Women, bureaucracy, development, diversity management, public service

\section{Introduction}

The history of women in Nigeria's public bureaucracy presents an account of tremendous diversity in the civil service. There can be no mistaking in the widespread and presence of women in the civil service of Nigeria toady. Yet female senior public administrators are relatively rare. In Nigeria today, equality for women in the civil service is improving, but upward mobility is still very slow. After almost five decades since Nigeria became independence nation-state and some experience with quota system and federal character, there can be absolutely no doubt about major gain in the opportunity that become available to women and minority groups in the civil service. However, prejudice continues to exist, as does the glass ceiling that limits women from enjoying truly equal opportunities in the Nigerian public service. Why is this ease? Although sufficient time may not have passed to more women to work their way into the senior positions of the Nigerian civil service, there appear to be more formidable barriers. Most notably, it is clear that powerful gender role stereotypes persist, narrow- minded beliefs about the kinds of tasks for which women are most appropriately suited. These beliefs originated from religious and in some cultural practices (Adeniyi, 1993). Women in Nigeria have virtually no formal power in the national and state civil service. Although the national government created Ministry of women affairs almost three decade ago, there is no doubt that the government shapes and limits women's role in the civil service. Gender is still central to understand the processes through which appointments are made to senior public management positions. Even though the government sometimes promote and patronize 
women's organizations, Nigerian women are still struggling to find ways to break the glass ceiling impose on them in the civil service. Well educated women in the civil service in Nigerian continues to face numerous contradiction between what they need to survive and what is possible under current administrative laws, religious, and traditional social structures in the country (Mukoro, 2020). Some studies that mentioned gender helplessness in African civil service argued that gender does shape the opportunities and constraints women and men face in securing positions in government (Thomas-Sayter \& Rocheleau 1995; Adepoju 1994; Kalu 1993). Moreover, as Adepuju pointed out, the systematically inferior position of women inside and outside the civil service and household in Nigeria points to the necessity of treating gender as a force of its own in sustainable development issues in the nation. Although the relative deprivation of women when compared with men varies around Africa, this fact does not diminish the importance of giving women more senior public management positions in Nigeria. If policy is to reach the citizens equitably and the grassroots with effective prescriptions and action for sustainable management of Nigeria's public resources, it will have to address the concerns of women not hired in senior public management positions (Adepoju 1994).

This paper therefore examines the predicament of prejudice on women in the public service in Nigeria and the struggle to integration women into political leadership and economic development in Nigeria. The paper argues that the Nigeria's public sector need to introduce diversity management programmes as a policy that should be adopted by the national, state and local governments. It further argues that in offering women the opportunity to access economic resources as well as to disentangle their identities from those of their families, women will contribute immensely in the sustainable development process in the nation. Furthermore, diversity management programmess will provide the space for women in Nigeria to clearly define their role as equal partners in the sustainable development process of the nation. This paper also presents some theoretical perspectives of women's roles in the development process of a nation. The concluding section of this paper calls for an equal opportunity' government policy that will effectively reduce discrimination against women in the civil service and integrate women's interests, social expectations and creation of opportunities for broad economic, social and political participation for all Nigerian women.

\section{Women and Equal Opportunity}

The study of feminism and equal opportunity in Nigeria is still in its infancy. Recently, attention to the impact of gender and ethnicity on public institutions has focused largely on perceptions of discrimination, the notion of representative bureaucracy and equal opportunities policies. Most African scholars have argued that the use of the word family is too restrictive and should be replaced with the term intimate. Since current research include studies of couples that cohabitate but are not necessarily married (Abdullah, 1995; Adepoju, 1994; Bank, 1994; Dennis, 1987; Konjo, 1991; Ofei-Aboagye, 1994; Wallace, 1999) the word family might not be appropriate. However, most scholars now accept the idea that a family unit may exist without any form of sanction such as marriage ceremony. In this paper, the definition of family includes the situation in which individuals are living together regardless of whether they are legally married or not. 
There is widespread acceptance of the critical role played by women and public institutions in the development process (Turner \& Hulme (1997; World Bank (1997). Women act as major actors in the transformation process, whether in terms of their direct involvement in the economy or their more tempered role as catalyst, facilitator and regulator of economic activity. At the same time a growing concern with the representatives of women and the management of diversity within Nigeria's public sector has been a concern. The concern of unequal representation of women in the public sector has affected reform efforts that put stress, human resources management issues such as capacity-building, participatory management styles, constant innovation, entrepreneurial initiative, teamwork, strategic thinking and planning as crucial. World Bank (1997) report pointed out that when women are not offered equal opportunity in the civil service there is the danger that some skills in a nation will be wasted. The idea that recruitment and promotion are based on merit rather than on some particularistic criteria can contribute significantly to higher levels of morale and performance. As Esman (1997) has pointed out, ethnic politics largely ignores public administration or socioeconomic development, in much the same way that the literature on economic development overlooks ethnic cleavages. Yet in many societies, particularly in Nigeria ethnicity and gender play such a fundamental, all- pervasive role in the development process. Ethnicity and gender politics is described as an important dimension in public affairs, pervading the environment in which public administration functions in Nigeria (Ayeni, 2014).

Appointments in the bureaucracy should be allocated among men, women and other different segments of the population in direct proportion to their members. This way, the administrative apparatus of Nigeria will becomes a microcosm of the wider society. However, this approach is clearly impractical in Nigeria for three main reasons. In the first place, it fails to recognize that social groups may not be equally predisposed to seeking careers in the public service. To the extent that this is true, the public service of Nigeria will never be fully representative on the basis of proportionality. This had always been the main defense (or rationalization) offered to explain the notable absence of women in senior management positions in the public service. It was argued that they did not apply as they preferred to seek employment in agriculture or commerce (Kalu, 1993; Bade, 2009; Malemi, 2013)). Second, not all groups are qualified to enter based on merit. As Otobo (1999) and Oluwo (1999) pointed out, representative bureaucracy in Nigeria depends on an even distribution of formal education. That is, women in the Nigerian society may be underrepresented in the public sector due to historical, religious and cultural patterns of educational development.

The level at which the bureaucracy ought to be representative is a third problem. Kolawole (1998) and Malemi (2013) argued that socialization experiences among women within the public service tend to diminish the influence of pre-employment experiences, and that upwardly mobile public servants are likely to hold different values and opinions from others with the same social origins. Greenberg (1999) and Bateman and Snell( 2011) contend that when one think of a mentor, the image that comes to mind is an older male senior executive helping a younger male junior executive work his way up the public service ladder by introducing him to the "old boy network." By definition, any old boy network is sexist. Indeed, women in Nigeria's public service often seem to have less access to suitable mentor than do men. Kolawole (1998) presented three reasons why men have more access to mentor than women did. First, there are simply fewer female executives 
available to serve as mentor for young female employees. Second, women are less willing to enter into mentoring relationships because they anticipate greater risk than men in doing so. Recent survey in Nigeria found that women expressed more concern than men did about the potential for negative exposure that might come from the increased visibility they assume because of their protégés (Mukoro, 2019). This is specifically very important because Nigeria do not have sexual harassment laws. Third, barriers to mentoring exist not only between men and women, but also between members of different religious and ethnic groups. Insofar as mentors and protégés often get together because they have similar backgrounds and share similar attitudes, it is not surprising to find that people from different ethnic and religious groups face difficulties in their mentor- protégé relationships - if they form one at all.

Adamolekun (1999) pointed out the current wave of public sector reform efforts that tacitly approves of an expanded role for technocratic advisors from outside the public sector. The reform policies certainly reduced the role of senior public servants as the sole source of policy advice and almost banishing them to implementation and administration issues. This role also makes it difficult for them to introduce programs that would eliminate discrimination against women. Far from being loyal to their nation, these senior public administrators are more likely to be loyal to their ethnic group and the political hand that feeds them. Thus prejudice against women continues to exist in the civil service of Nigeria, as does the glass ceiling that limits all women from enjoying truly equal opportunities in the nation (Mukoro, 2020).

In the Nigerian public service, the marginalization of women in the nation has two contrasting gender ideologies, which ironically produce the same outcome. The first is related to the aforementioned state- promoted gender identity. "The state rhetoric and action imply that women in Nigeria do not need to engage in income-generating activities and that those who do engage in such activities do so for reasons other than economic necessity. The second gender ideology under girding the marginalization of women microentrepreneurs is related to gender bias embedded in development practice that perceive women as vulnerable and isolated groups and their activities as a collection of inconsequential endeavors. Gender specific ideologies; such as these, which underpin the marginalization of women within the public sector of Nigeria, are often nuance by cultural, ethnic and religious undertone” ( Gberevbie, 2017: 17).

In Nigeria, the rigid and hegemonic nature of prevailing notions of work not only denigrates the work of women but dis-empowers women producers themselves. Interview conducted in Nigeria in summer of 2020 reveals that, although women consider themselves to be producers of goods and providers of services for a large segment of the society, like the society women have a low estimate of the value of their own labor. Hence, it would seem that the particular constructions of gender to which Nigeria working women are subject and which inform their notions of self, not only deny them the value of their daily activities but also undermine the potential of their ministry or public agencies and discourage them from developing enabling notion of self worth. Finally, the large scale exclusion of women from mainstream senior public management positions and political position at the national, state and local governments despite the fact that they are in majority in the nation serves to reinforce this situation (Mukoro, 2020). 


\section{Policies towards Equality of Opportunity for Women}

While the passive approach emphasizes the sociological or demographic representatives of the Nigerian public service, the active approach places the accent on the cultural, religious and political determination of discrimination against women. From this perspective arise policies such as equal opportunity and other ethnic-conscious instruments designed to benefit the marginalized groups. "Equality of opportunity is predicated on the idea of fair competition on the basis of merit, and the role of public policy is to ensure that all qualified individuals (men and women) may enter the competition and be judged according to the same criteria. Therefore, the state must act to (1) ensure that the competition is equal, and (2) equalize starting points where necessary" (Lovenduski 1989: 8). There has been much debate and political controversy surrounding equal opportunity policies and quota system in Nigeria. At the heart of the debate is the question of whether preferential treatment is justified and, if so, on what grounds. While accepting that there may be reason to challenge the arbitrary criteria on which preferences are to be allocated, there is no alternative but to support Edward's (1995) and Armstrong's (2012) position that, in principle at least, they (i.e. preferences to one or other group) are acceptable once they are designed to remove inequality and do not create greater injustices than those they seek to overcome.

Diversity ought to be an end in itself and not a means to achieving some less noble, politically motivated objective. Second, if that equal opportunity is intended to serve as compensation for past injustices, then it is flawed as a form of redress since there is seldom anything that links past victims and present beneficiaries. What it does, in effect, is to seriously devalue (or certainly undervalue) the worn-; qualifications of those whose forebears stand accused of discriminating against previous generations of the new "ingroup.” This is surely Niger tantamount to replacing one system of injustice with another. Government not only must understand the dynamics of family abuse, but also be prepared to offer support and guidance to victims as they move through the difficult period in their life. Repairing the body and spirit is only half the battle; society must be able to make the victims of family abuse completely whole. This has to include financial reimbursement from the offender (Mukoro, 2020). The people of Nigeria are beginning to association except the fact that victims of crimes in general and victims of family abuse in particular, have rights and need to be active participants in the criminal justice system. This includes giving their input during sentencing of offenders. The use of victim impact statements is a giant step forward for victims of family violence.

The various policy instruments for ensuring women development are not exclusive to the government's official policies. "Legal aid and legal marked literacy are the most popular components of government's effort to reduce family abuse. To rectify this situation in Nigeria, the Family Law Center is a legal services advisory center offering free legal advice on all family women legal problems to low income people. The center's founders were careful not to restrict its service to women because of fear that it would be stigmatized as another 'women's liberation project'. Such a legal might have jeopardized the centers existence for number of reasons. There are some non-official women organizations or associations that are committed to women's development. These non-governmental associations include Association of Working House Wives, Association of Media Women, Army Officers Wives Association, and National Council of Women Society of Nigeria and 
so on. The interests of these groups are basically confined to the welfare of their members. The activities of the National Council of Women for example, include the operation of child welfare services scheme, and market nurseries to cater for the children of market traders. The council runs adult education programs aimed at increasing political awareness and participation of women in development with particular references to women franchise - the right to vote and be voted for. It also runs a number of hostel accommodations for women in various towns and cities in Nigeria in other to alleviate accommodation problem for women in urban centers" (Nwaagbara, 2016: 13).

The formal instrument for women development in the Nigerian administration is the Federal Ministry of Social Development, Youth and Sports. Broad policies and guidelines on women development emanate from this ministry. Prominent among such development programs is the Community Home Economics that include day care center management. This is designed to enlighten women in rural areas on modern methods of home keeping and childcare. Another women development program is the Community Development Training Center. The center undertakes the training of rural women, teachers, and front line women leaders to enable them to motivate the citizens towards undertaking self help projects and to handle the various Day Care Centers (Buchanan, 1993; Udegbe 1999). The Adult Education program of the Federal Ministry of Education though not an exclusive women policy affair has also presented policy instrument for enhancing women development. Women are largely illiterates in comparison with their male folks and would therefore benefit more from adult education programs of the federal and various state governments. It is pertinent to note that a National Education Agency has been set up by the federal government and, subsequently all the state governments have been directed to set aside five percent of their capital budget on education for the agency (Ibe, 1994).

The Nigerian government has started operating a scholarship scheme for interested female candidates that do exceptionally well in science; technology, mathematics and other sciences related subjects. Two technical colleges have been devoted to the enhancement of women development in the country (Buchanan, 1993; Getachew, 2014). Also indicative of government policy, is the use of mass media to propagate women education. In this vein, both the federal education ministry and state governments seek to encourage parents to send their female children to school. In most Northern states, the official position is to prosecute parents who either withdraw their daughters from school for marriage, encourage their daughters to trade on the streets or farm. The government has also established the Commission for Women's Affairs to enhance the status of women socially and economically. In addition, the government has issued decrees abolishing abuses against women, improving their health status discouraging such practices as early marriage and female circumcision. The President of Nigeria, Olusegun Obasanjo announced the establishment of a new Ministry for Women Affairs in his 2000 budget speech; this is a continuation of General Sani Abacha's legacy of 1995. The rationale for women's ministry is that it will encourage them to enter the labor force and supply a wide range of talents and services demanded by the general public. This in turn will improve productivity and economic growth of the country. In the management of business and industry, however, women are conspicuously absent. It is not the technical, but the sociological aspects of industrial and business management that militates against success for women in the occupation ( Gberevbie, 2017). 
Further political pressure on multinational corporations, governments, lenders and international donors by men and women dedicated to sexual equality will be vital to ensure that women's interests are not neglected. "These groups range from rural cooperatives to occupational associations, to urban business enterprises, to social welfare, church, and entertainment groups. Although they may not have originated as such, many of these groups have developed an expressly political focus. Through the use of these nongovernmental organizations (NGOs), women's protest has assumed widely divergent forms; some organizations are seeking to politicize the private domain in certain contexts. Nonsexist education and training for women and men as well as equal access to jobs, property, and leadership positions must be provided. Nigeria will not achieve its development goals if women's full humanity and citizenship is not acknowledge and vigorously protected. Even if legal reforms make the economic situation of wives more secured, Nigerian men must be educated on other ways to boost their ego, redirect their anger and curb their chauvinism. Beating ones' wife is surely not an option. The media should be used to educate the people of Nigeria, that cultural values that encourage family abuse are no longer valid in the twenty-first century. Finally, Nigerian women should realize that the degree of success that they will experience in curtailing any opposition from men and in averting gender stereotype in the nation is dependent on their ability to enlist men as allies. The extent to which this would be possible in Nigeria hinges on women's ability to convince men that their new social space and new gender identities are nonthreatening, mutually benefiting, and greater than a zero-sum game. In the twenty-first century Nigeria should change the notion of women as specialized homemakers and men as providers. There should be a mutual understanding that both women and men have the obligation to participate in the labor market regardless of gender and domestic responsibilities” (Nwaagbara, 2016: 125).

\section{Gender Factor in Development}

Women being agents of development is a historical fact and it is a disservice for any country (including Nigeria) to ignore its women population in its development efforts. Therefore, the need for effective participation of women in development should be compelling. Equal opportunities should be provided to them and their male counterparts, both of whom should be seen as partners in, progress (Ebosele, 1993; Adepoju, 1994). This partnership role of women in development is slowly being accepted in Nigeria. In Nigeria feminism obscures the essential struggle and lumps together into interests that might even be practically opposed. The various professional bodies of women and those which are versions of all the political parties in the country today operate to further consolidate a system which opposes the interests of workers and peasants (men and women) alike. They also work principally to advance their own corporate interests and not that of women in general and in abstraction. The "glass ceiling" and the "glass wall" are phrases that were coined to illustrate the obstacles that hinder upward mobility or lateral movement of women in the work place. Many articles offer explanations for the disproportionately low number of women in leadership positions, all of which focus on barriers that keep women from rising in corporations (Malemi, 2013).

It is only when women are freed from the current property relations that they could be regarded as fully liberated. For other injustices which are largely psychological and 
social, such a humiliation, over lordship, family abuse, etc., are formed on this basis. The World Bank (1989) summarizes the economic plight of women: "Modernization has shifted the balance of advantage against women. The legal framework and the modern social sector and producer services developed by the independent African nation (and also most externally sponsored development project) have not serviced women well. Legal systems have discriminated in land titling ... It is often more difficult for women to gain access to information and technology, resources, and credit. Agricultural extension and formal financial institutions are biased towards a male clientele ... There is a wider gender gap in education. As a result, women are less equipped than men to take advantage of the better earning opportunities” (World Bank, 1989: 86-87). The process of development and urbanization has fortunately liberated a small minority of educated Nigerian women. Many of these professional women play prominent roles in international forums for equal rights, status redress and the emancipation of African women. At the Fourth Regional Conference on Women in Lagos, 1989, Nigerian's formal military leader, General Babangida noted that ... "There are compelling reasons why African women must be integrated in the development process. First is their numerical strength ... They are industrious and enterprising ... They are good managers ... No national development program will be meaningful and thorough if women are not fully involved” (Buchanan, 1993; Udegbe 1999). Nigerian women want to be integrated on an equal footing in the ongoing development process for greater efficiency.

The constraining factors in the advancement of women to the same status as men in Nigeria are daunting in many respects. Therefore in eliciting women participation in development, their inhibiting factors need to be identified and removed in order to equalize access to opportunities. In the past, women's role in most countries of the world was confined solely to the kitchen and other domestic activities. This view of women's role is still largely held in most African countries, including Nigeria. Women in West Africa are consciously, deliberately and perpetually considered as subordinate to their male counterparts as a matter of tradition and culture that must be unchangeable. In this vein, the relationship between women and their counterpart is that of unequal partners (Malemi, 2013). This discriminatory practice against women's positive contributions to development has not been obliterated as logically expected from there under development, and unequal access to development opportunities. The importance of this assertion becomes clear when we take a historical excursion into Nigeria's past and even contemporary experiences. For example, Nigeria's political developments in the pre-colonial era cannot be correctly written or understood without the mention of effective leadership of women like Queen Amina of Zaria, who was renowned for her series of conquests and political domination of parts of the old northern states, and Queen Idia of Benin who provided an effective military bastion for her son, Oba Esigie of Benin (Mba, 1982). On this basis, Udegbe (1999) and Awe (1994) pointed out that during pre-colonial times women were not left out in the political arrangement. Women's political power varied from one place to another and in some societies they shared equal power with men.

\section{Conclusion}

This paper examines the issue of managing diversity in the civil service of Nigeria. It argues that the public sector of Nigeria need to introduce diversity management programs 
as a policy that should be adopted by the national, state and local governments. The paper also argues that in offering women the opportunity to access economic resources as well as to disentangle their identities from those of their families, diversity management programs will provide the space for women in Nigeria to clearly define their role as equal partners in the sustainable development process of the nation. The proposed diversity management programs should serve as a key instrument in the recruitment and promotions, and suggests ways in which subjective perceptions of discrimination can be minimized. Transparency is critical. Public disclosure of entrance requirements and examination results, and even of the rationale for confidentiality where this is felt unavoidable, can ensure that injustice and unfairness are met with public censure. The composition of interview panels must be sensitive to issues of ethnicity as well as gender. Promotions must be subjected to similar pressures. It has been argued that a proper functioning performance appraisal system is indispensable if any element of subjectivity and bias is to be removed from the promotion process. Furthermore, to make a performance appraisal system function effectively, reporting officers should be exposed to training in personnel and diversity management as a matter of course, if only to help develop an appreciation for public personnel management and the importance of performance appraisals within it. It cannot be assumed that those charged with this responsibility are endowed with the knowledge and understanding to treat staff appraisal as a continuous process that begins with the development of a classification system and adequate job descriptions, and is reinforced when public officers agree with their supervisors on specific, measurable, achievable, realistic targets/outputs to be delivered over a given period of time (e.g. quarterly).

Underlying all of this, however, must be the establishment of procedures for conflict resolution at the workplace and a clear-cut and inexpensive grievance procedure that permits public officers who feel they have been discriminated against on ethnic (or any other) grounds to lodge complaints with a competent authority. Subjective perceptions of discrimination are every bit as serious - perhaps even more serious - than discrimination that can be proved to exist on objective criteria. Indeed, the grave danger is in assuming that if allegations of discrimination cannot be substantiated, then it does not exist. As long as it continues to exist in people's minds, the problem will remain a festering sore. In the twenty-first century, the Nigerian government's civil service needs a new paradigm in the work place that links ability with skill, rather than ability with gender. The precise nature of the jobs assigned to men and women is not important in itself. What is important is that jobs should be given to the people with the right qualifications or skills. Gender typing will not help the country attain its industrialization goals. Given Nigeria's critical economic and political problems, it appears increasingly obvious that suppressing the talents and skills of women in order to protect men's privileges is an enormous waste of human resources that the country can no longer afford. The present situation does not meet the criterion of "the best person for the job.” It therefore implies a kind of prodigality that those concerned with public interest can hardly be viewed with equanimity. Limited gains toward gender equality suggest a reality at odds with seemingly fairer policy formulation. Although some bureaucratic structures are in place to provide for equal wages and equality of opportunity for women's economic position in relative to men's have eroded. With concrete resolution of the constraints militating against women's participation in development, Nigeria will move faster in its sustainable development and industrialization process. In conclusion 
therefore, the success of the government will increase if it is determined by its managers' ability to naturally tap the full potentials of a diverse workforce that comprise of men, women and young adults

\section{References}

1. Abdullah, A. (1995). Wifeism and Activism: The Nigerian Women's Movement. In the Challenge of Local Feminisms: Women's Movements in Global Perspective edited by AmeritaBasu. Boulder, Colorado: Westview.

2. $\quad$ Adamolekun, O. (1999). Public Administration in Africa.Boulder, Colorado: Westview

3. Adeniyi, T. (1993). Biography of Chief (Mrs.) H.I.D. Awolowo. Lagos, Nigeria: Daily Times Press.

4. Armstrong, M. (2012). Armstrong's handbook of human resource management practice (12thedition). London: Kogan Page.

5. Awe, B. (1994) Nigerian Women in Historical Perspective. Ibadan: Sankore/Bookcraft.

6. Ayeni, J. (2014). Management of change: A re-orientation of the public and civil service in Nigeria. Lagos: The Institute Of Information and Records Management Publications.

7. Adepoju, Aderanti. (1994). The Demographic Profile: Sustained High Morality and Fertility and Migration for Employment. In Gender, Work and Population in Sub-Saharan Africa, edited by AderantiAdepoju and Christine Oppong. London: J. Currey.

8. Bade, C. C. (2009). Principles of public administration in Nigeria. Ibadan: University of Ibadan Press.

9. Bank, L. (1994). Angry Men and Working Women: Gender, Violence and Economic Change in Qwaqwq in the 1980s. African Studies Vol. 53, 1, pp. 89 - 114. https://doi.org/10.1080/00020189408707790

10. Bateman, T. S. \& Snell, S. A. (2011). Management: Leading \& collaborating in a competitive world (9th edition). United States; McGraw-Hill.

11. Buchanan, Enid. (1993). Women: Struggle for Change. West Africa, (November 1-7), pp. 21-23.

12. Dennis, C. (1987). Women and the State in Nigeria: The case of the Federal Military Government, 1984-1985. In Women, State and Ideology: Studies from Africa and Asia edited by HalehAfshar, pp. 13-27. Albany, New York: SUNY Press.

13. Ebosele, Moses. (1993). Political Emancipation of Women. The Nigerian Observer, Benin City, Nigeria.

14. Edwards, J. (1995) When Race Counts The Morality of Racial Preference in Britain and America. London: Routledge.

15. Esman, Milton (1997) Public Administration, Ethnic Conflict, and Economic Development. Public Administration Review, Vol. 57, 6, pp. 527-33. https://doi.org/10.2307/976964

16. Getachew, R.H. (2014). Civil service reform in Ethiopia: Success in two ministries. Journal of Law and Politics of Globalization, 4, 1-16.

17. Greenberg, J. (1999). Managing Organizational Behavior. Upper Saddle River, New Jersey: Prentice Hall.

18. Ibe, Iro. (1994). A Look at the Gender Conflict in Africa. Lagos, Nigeria: The Punch Press.

19. Kalu, W. J. (1993). Battered Spouse As a Social Concern in Work with Families in Two Semi-Rural Communities of Nigeria. Journal of Family Violence, Vol. 8, 4, pp. 361-373. https://doi.org/10.1007/BF00978099

20. Kolawole, M. (1998). Gender Perceptions and Development in Africa. Lagos, Nigeria: Arrabon Academic Publisher.

21. Konjo K. (1991). Nigerian Women's Participation in National Politics: Legitimacy and Stability in an Era of Transition. Michigan State University Working Paper, 221.

22. Lovenduski, J. (1989) Implementing Equal Opportunities in the 1980s: An Overview. Public Administration, Vol. 67, pp. 7-18. https://doi.org/10.1111/j.1467-9299.1989.tb00710.x

23. Malemi, E. O. (2013). Administrative law (4th edition). Ikeja: Princeton Publishers.

24. Mba, N. E. (1982). Nigerian Woman Mobilized: Women's Political Activity in Southern Nigeria 1900-1965. Berkeley: University of California. 
25. Mukoro, A. ( 2019). Public administration: Practice and theory in Nigeria. Ibadan: Ababa Press Ltd.

26. Mukoro, A. ( 2020). Administration of the public service. Ibadan: Ababa Press Ltd.

27. Nwagbara, C. (2016). Administrative law as the bedrock of administrative agencies in Nigeria. International Journal of Business and Law Research, 4 (1), 9 - 16.

28. Ofei-Aoagye, R. O. (1994). Altering the Strands of the Fabric: A Preliminary Look at Domestic Violence in Ghana. Signs, Vol. 19, 4, pp. 924 -940. https://doi.org/10.1086/494945

29. Olowu, D. (1999). Accountability and Transparency. In Public Administration in Africa edited by Oladipo Adamolekun. Boulder, Colorado: Westview

30. Otobo, E. (1999). Nigeria. In O. Adamolekun (ed.). Public administration in Africa. Boulder, Colorado: Westview

31. Thomas-Sayter, B., \& Dianne, R. (1995). Gender, Environment and Development. Boulder, Colorado: Lynne Rienner Press.

32. Turner, M., \& Hulme, D. (1997) Governance, Administration and Development: Making the State Work. London: Macmillan Press.

33. Udegbe, B. (1999). The Constitional Conference, Political Restructuring and Women's Access to Power. In K. Amuwo, R. Suberu, A. Agbaje \& G. Herault(eds.). Fedrealism and Political Restructuring in Nigeria. Ibadan, Nigeria: Spectrum Press.

34. Wallace, H. (1999). Family Violence: Legal, Medical, and Social Perspectives. Boston, Massachusetts: Allyn and Bacon

35. World Bank. (1989). Sub-Sahara Africa: From Crisis to Sustainable Growth: A Long Term Perspective Study. Washington, DC: World Bank.

36. World Bank. (1997). World Development Report 1997. New York: World Bank. Creative Commons Attribution - Non Commercial - No Derivatives 4.0 International License. 